\title{
A DIRECT METHOD FOR THE ESTIMATION OF SKIN DISTENSI- BILITY WITH ITS APPLICATION TO THE STUDY OF VASCULAR STATES
}

\author{
By WILliam A. SODEMAN and GEORGE E. BURCH \\ (From The Department of Medicine, Tulane University of Lonisiana and The Charity \\ Hospital of Lonisiana, New Orleans)
}

(Received for publication July 19, 1938)

Schade (1) first introduced objective quantitative methods for the study of the physical characteristics of human skin when, in 1912, he described an elastometer designed to indicate skin elasticity. Since that time many modifications of his method have appeared $(2,3,4,5,6,7,8)$. The present report is an attempt to study the physical characteristics of the skin, not by changes as influenced by therapeutic procedures where heretofore no satisfactory quantitative methods have been available.

\section{APPARATUS}

The apparatus is illustrated in Figures 1 and 2. Figure 1 illustrates the apparatus in use, while Figure 2 demonstrates the details of construction. It consists

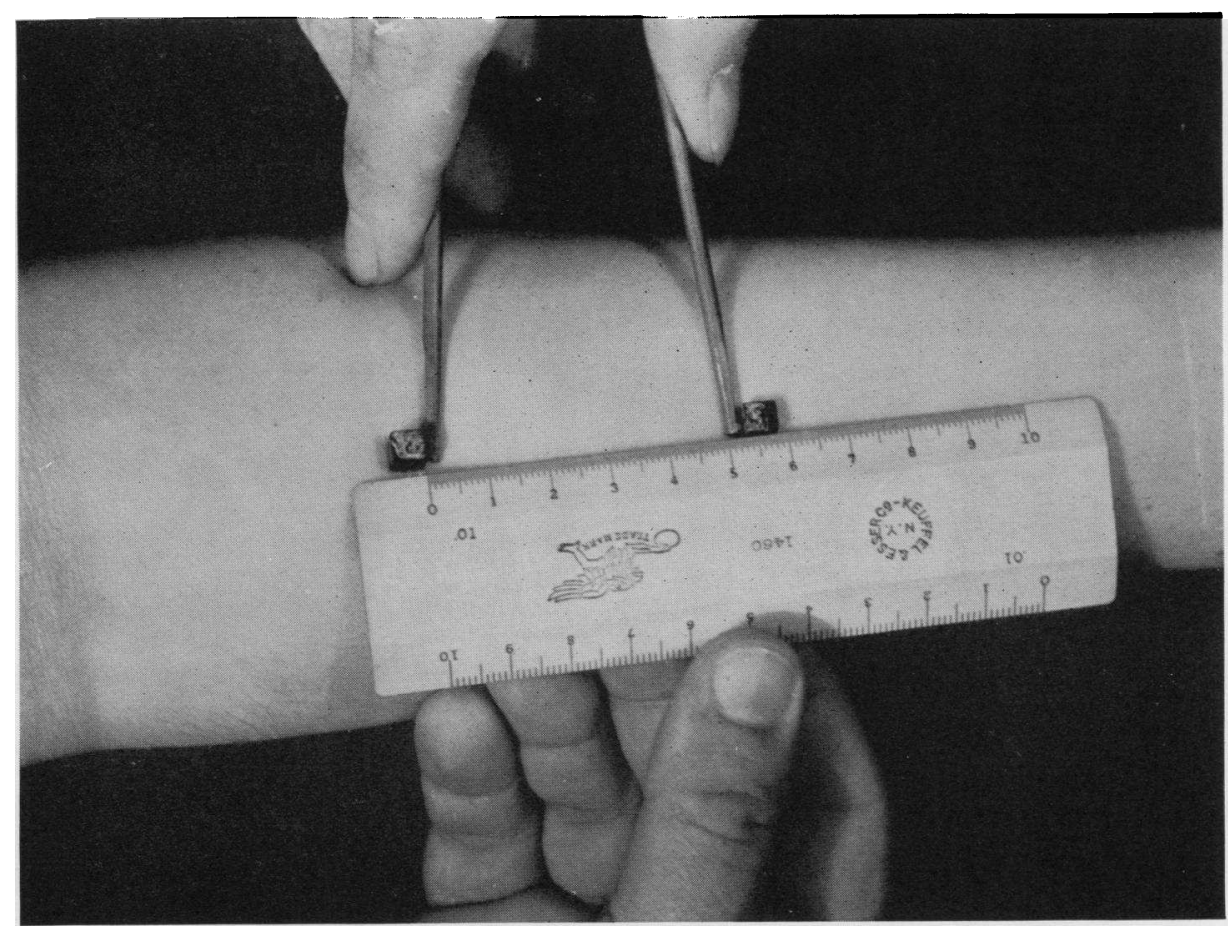

Fig. 1. The Apparatus in Use

Schade's method or its modifications, which are essentially adaptations of the tonometer principle as applied to the eye, but by an apparatus designed to measure the distensibility, or "stretchability," of the skin, and thus to evaluate this physical property in normal and pathological physiology. Applications of the method have come to light for the objective estimation of certain skin essentially of four parts, a spring caliper, $A$; two bakelite cubes, $B$; and a brass adapter, $C$. The caliper consists of two rigid brass arms, $b$, which are sealed with DuPont household cement to the ends of a steel spring, $a$. The spring and length of the arms of the caliper were so chosen that when the knife-edges of the distal ends of the arms are $5 \mathrm{~cm}$. apart, these knife edges tend to separate with a force of approximately 100 grams.

The caliper was calibrated as follows. One arm of the caliper was fixed in a vise so that the knife edge of 
the other arm rested directly above that of the fixed arm. A square piece of bakelite, $4 \mathrm{~mm}$. on edge and $2 \mathrm{~mm}$. thick, was grooved on one of the wide surfaces through the center and parallel to two edges. The bakelite square was balanced with the groove articulating with the upper knife edge, and weights freely suspended from it by means of a loop of twine. Weights were suspended in increments of 5 grams from 0 to 150 grams, at both ends so that there are two surfaces parallel to each other and $5 \mathrm{~cm}$. apart.

In use, the skin surface is carefully cleansed with ether in order to remove the sebaceous secretions. The bakelite cubes are then loosely sealed, with Johnson and Johnson's zinc oxide adhesive mass, into the notches of the adapter so that the grooved surfaces face each other $5 \mathrm{~cm}$. apart with the central groove perpendicular to the
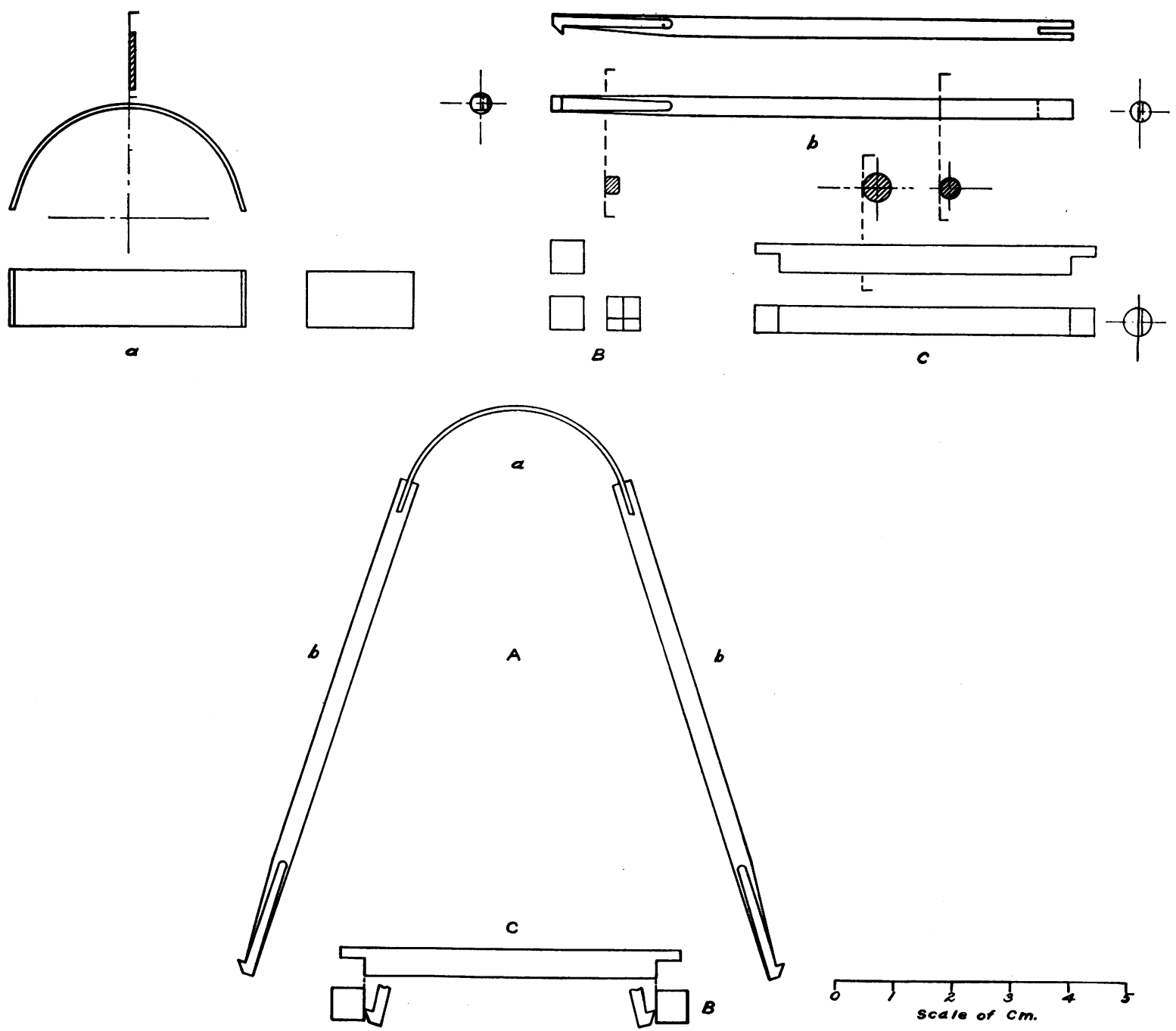

Fig. 2. Details of Construction of the Apparatus

adjustments being made to keep the line of force directly between the knife edges. The distance between the knife edges was determined to $0.1 \mathrm{~mm}$. for each 5 -gram increment by means of a hand lens and scale. The results are illustrated in Figure 3 . The formula for the line was found to be Force $=257.6-2.773$ distance. Recalibration of the instrument after three months of use failed to reveal any change in its characteristics. A surface in each of the cubes, $B$, is grooved as illustrated in Figure 2. The brass adapter, $C$, is notched adapter and the eccentric groove away from the adapter. The cubes are then placed upon the previously prepared skin with the adapter above. The cubes are then sealed to the skin with a thin layer of fresh collodion carefully applied to the junction of the cube and the skin on all sides except the grooved surfaces which face each other. After five minutes have been allowed for the collodion to dry, the adapter is carefully removed, leaving the bakelite cubes sealed to the skin with a distance of approximately $5 \mathrm{~cm}$. between them. The distance between 
the cubes is then accurately measured to $0.1 \mathrm{~mm}$. with a scale. With the calipers held horizontal to the skin surface and closed so that the knife edges are less than $5 \mathrm{~cm}$. apart the arms are then gently opened so that the knife edges articulate at the skin surface with the vertical grooves of the bakelite cubes. All pressure on the caliper arms is then released so that they open with the distensibility of the skin in any convenient terms. We have chosen millimeters of stretch per centimeter of skin per 100 grams of force. The force exerted by the caliper is determined by referring to the graph of Figure 3 upon which the millimeter distance between the cubes, when the pressure on the caliper arm is released, may be converted into force exerted in grams.

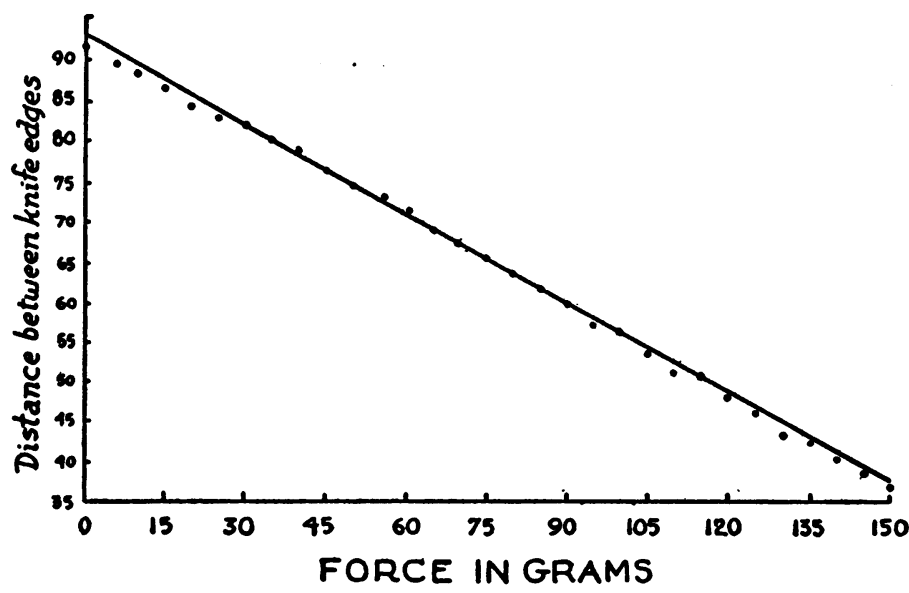

Fig. 3. Calibration Curve of the Caliper

their full force. The distance between the cubes is then remeasured. Care must be taken to maintain anatomical structures in the area studied in the same relative positions for determinations from patient to patient and for determinations from time to time in the same patient. Such a standard position for the part is extremely important as will be discussed later.

Knowing the initial and final lengths of skin segment and the force exerted by the caliper, one may express
The same data may be obtained from the formula already given.

\section{RESULTS}

Determinations were made on 13 normal subjects for the pretibial area, dorsum of the foot, midline of the abdomen below the umbilicus, volar surface of the forearm and the dorsum of the

TABLE I

Distensibility studies in 13 normal subjects

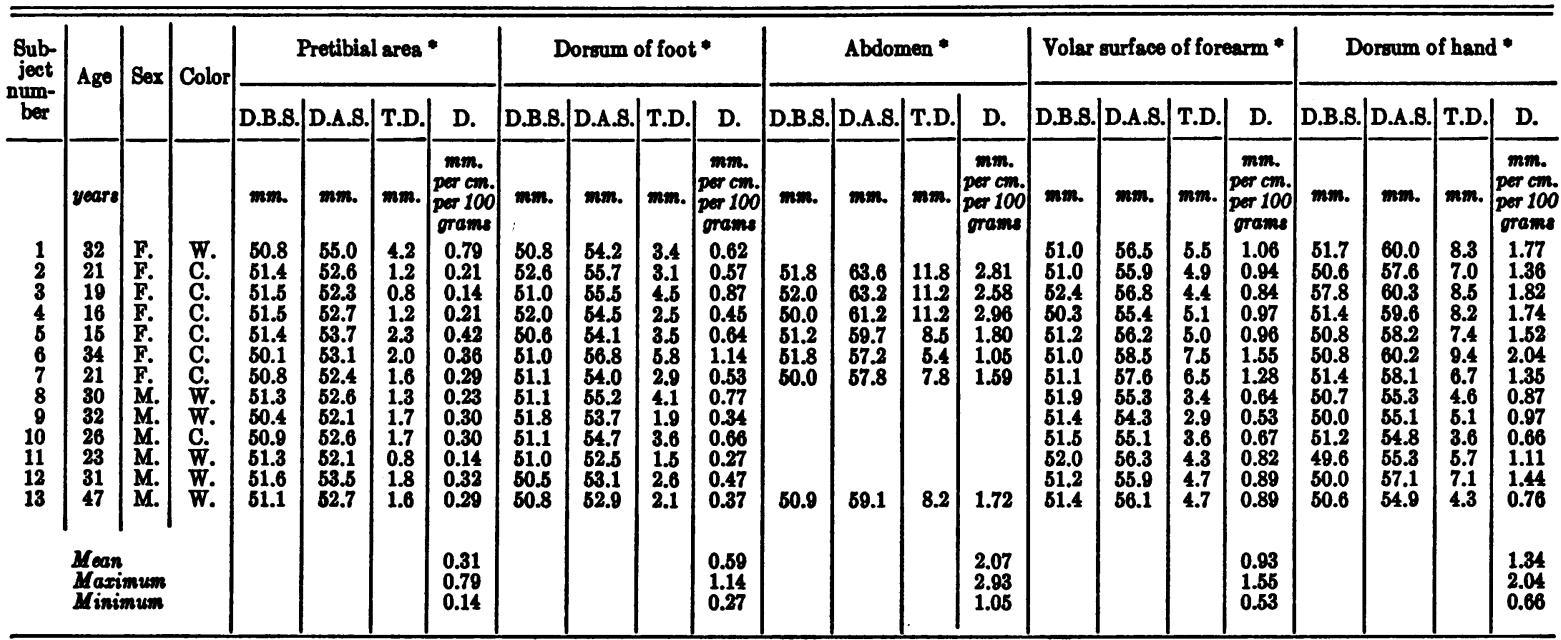

*D.B.S. = Distance before stretching; D.A.S. = Distance after stretching; T.D. = Total distance stretched; $\mathrm{D}=$ Distensibility. 
hand, always in a direction parallel to Langer's lines of skin elasticity (9). These sites were chosen because of the frequency of edema and various dermatoses in these areas. Results are

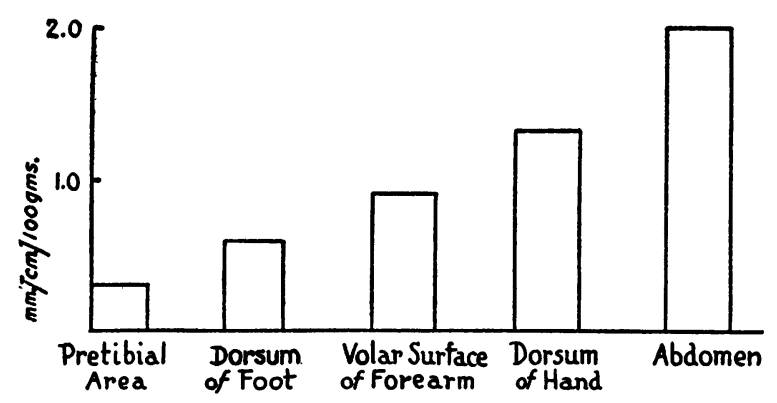

Fig. 4. Mean Skin Distensibility Values of 13 SubJects

illustrated in Table 1. The mean values were found to be $0.31,0.59,2.07,0.93$, and $1.34 \mathrm{~mm}$. per $\mathrm{cm}$. per 100 grams respectively. The individual determinations may be found in Table I. One can see that the skin is less distensible in the lower extremities. This is graphically illustrated in Figure 4. These values vary inversely with the values previously determined for tissue pressure in the same areas (10). Determinations were repeated 15 times on the volar surface of the forearm of one subject at intervals varying from 6 to 72 hours. Values varied from 0.87 to 0.98 $\mathrm{mm}$. per $\mathrm{cm}$. per 100 grams with a mean of $0.908 \pm 0.006$ and a standard deviation of $0.036 \pm 0.004$

The method has been applied to the study of certain abnormal states known to affect the skin. These results are recorded in Table II and Figure 5. In eight patients with congestive heart failure, 21 determinations have been made. Patients

TABLE II

Distensibility values in various pathological states

\begin{tabular}{|c|c|c|c|c|c|c|c|c|c|c|c|}
\hline $\begin{array}{c}\text { Case } \\
\text { num- } \\
\text { ber }\end{array}$ & Diagnosis & Age & Sex & Color & Date & Ares studied & $\begin{array}{l}\text { Dis- } \\
\text { tance } \\
\text { before } \\
\text { stretch- } \\
\text { ing }\end{array}$ & $\begin{array}{l}\text { Dis- } \\
\text { tance } \\
\text { after } \\
\text { stretch- } \\
\text { ing }\end{array}$ & $\begin{array}{c}\text { Total } \\
\text { distance } \\
\text { stretched }\end{array}$ & $\begin{array}{l}\text { Dis- } \\
\text { tensi- } \\
\text { bility }\end{array}$ & Remarks \\
\hline & & years & & & & & $m m$. & $m m$. & $m m$. & $\begin{array}{l}m m . \text { per } \\
\mathrm{cm} . \text { per } \\
100 \text { grams }\end{array} \mid$ & \\
\hline 1 & Congestive heart failure & 66 & F. & W. & $\begin{array}{l}\text { Deo. 16, } 1937 \\
\text { Dec. 20, } 1937 \\
\text { Deo. 20, } 1937 \\
\text { Deo. 22, } 1937\end{array}$ & $\begin{array}{l}\text { Left pretibial } \\
\text { Left pretibial } \\
\text { Left forearm }\end{array}$ & $\begin{array}{l}\mathbf{5 1 . 2} \\
51.1 \\
52.2\end{array}$ & $\begin{array}{l}52.4 \\
52.2 \\
57.1\end{array}$ & $\begin{array}{l}1.2 \\
1.1 \\
4.9\end{array}$ & $\begin{array}{l}0.20 \\
0.19 \\
0.95\end{array}$ & $\begin{array}{l}\text { Marked edema } \\
\text { Edems unchanged } \\
\text { Moderate edema } \\
\text { Patient deserted }\end{array}$ \\
\hline 2 & Congestlve heart fallure & 43 & M. & C. & $\begin{array}{l}\text { Jan. 12, 1938 } \\
\text { Jan. 13, 1938 } \\
\text { Jan. 17, 1938 } \\
\text { Jan. 20, 1938 } \\
\text { Jan. 21, 1938 }\end{array}$ & $\begin{array}{l}\text { Left pretiblal } \\
\text { Left pretibial } \\
\text { Left pretibial } \\
\text { Left pretibial }\end{array}$ & $\begin{array}{l}51.0 \\
51.6 \\
50.7 \\
51.9\end{array}$ & $\begin{array}{l}51.7 \\
51.8 \\
52.0 \\
54.2\end{array}$ & $\begin{array}{l}0.7 \\
0.2 \\
1.3 \\
2.3\end{array}$ & $\begin{array}{l}0.12 \\
0.03 \\
0.21 \\
0.41\end{array}$ & $\begin{array}{l}\text { Marked edema } \\
\text { Blebs developing } \\
\text { Edems decreasing } \\
\text { Very slight pitting edems } \\
\text { Patient died }\end{array}$ \\
\hline 3 & Congestive heart failure & 69 & M. & C. & Jan. 17,1938 & Left pretibial & 50.5 & 51.6 & 1.1 & 0.19 & Marked edema of long stand- \\
\hline 4 & Congeetive heart failure & 63 & F. & C. & $\begin{array}{l}\text { Jan. 20, } 1938 \\
\text { Jan. 21, } 1938 \\
\text { Jan. 27, } 1938\end{array}$ & $\begin{array}{l}\text { Left forearm } \\
\text { Left forearm } \\
\text { Left forearm }\end{array}$ & $\begin{array}{l}\mathbf{5 1 . 8} \\
\mathbf{5 0 . 7} \\
\mathbf{5 2 . 0}\end{array}$ & $\begin{array}{l}53.3 \\
53.8 \\
55.5\end{array}$ & $\begin{array}{l}1.5 \\
3.1 \\
3.5\end{array}$ & $\begin{array}{l}0.29 \\
0.56 \\
0.65\end{array}$ & $\begin{array}{l}\text { Marked edems } \\
\text { Edems decreasing } \\
\text { Edems decreasing. Patient }\end{array}$ \\
\hline 5 & Congestive heart failure & 60 & F. & W. & $\begin{array}{l}\text { Jan. 21, } 1938 \\
\text { Jan. 21, } 1938 \\
\text { Jan. 26, } 1938\end{array}$ & $\begin{array}{l}\text { Left pretibial } \\
\text { Left pretibial } \\
\text { Left pretibial }\end{array}$ & $\begin{array}{l}51.5 \\
51.3 \\
50.7\end{array}$ & $\begin{array}{l}53.6 \\
53.1 \\
52.7\end{array}$ & $\begin{array}{l}2.1 \\
1.8 \\
2.0\end{array}$ & $\begin{array}{l}0.38 \\
0.32 \\
0.36\end{array}$ & $\begin{array}{l}\text { Slight edema (a.m.) } \\
\text { Edema increased (p.m.) } \\
\text { Edema decreasing }\end{array}$ \\
\hline 6 & Congestive heart failure & 48 & F. & C. & $\begin{array}{l}\text { Feb. 8, } 1938 \\
\text { Feb. 9, } 1938 \\
\text { Feb. 10, } 1938\end{array}$ & $\begin{array}{l}\text { Right pretiblal } \\
\text { Right pretiblal }\end{array}$ & $\begin{array}{l}51.0 \\
50.3\end{array}$ & $\begin{array}{l}51.9 \\
51.6\end{array}$ & $\begin{array}{l}0.9 \\
1.3\end{array}$ & $\begin{array}{l}0.16 \\
0.23\end{array}$ & $\begin{array}{l}\text { Moderate edema } \\
\text { Edema receding } \\
\text { Patient died }\end{array}$ \\
\hline 7 & Congestive heart failure & 73 & M. & C. & $\begin{array}{l}\text { Feb. 21, } 1938 \\
\text { Feb. 22, } 1938 \\
\text { Feb. 24, } 1938\end{array}$ & $\begin{array}{l}\text { Right pretibial } \\
\text { Right pretibial }\end{array}$ & $\begin{array}{l}50.5 \\
51.2\end{array}$ & $\begin{array}{l}51.2 \\
52.1\end{array}$ & $\begin{array}{l}0.7 \\
0.9\end{array}$ & $\begin{array}{l}0.12 \\
0.16\end{array}$ & $\begin{array}{l}\text { Moderate edema } \\
\text { Edems unchanged } \\
\text { Patient died }\end{array}$ \\
\hline 8 & Congestive heart failure & 60 & F. & C. & $\begin{array}{l}\text { Feb. 28, } 1938 \\
\text { Mar. 2, } 1938 \\
\text { Mar. } 5,1938\end{array}$ & $\begin{array}{l}\text { Right pretibial } \\
\text { Right pretibial } \\
\text { Right pretibial }\end{array}$ & $\begin{array}{l}50.9 \\
50.8 \\
51.5\end{array}$ & $\begin{array}{l}51.9 \\
51.8 \\
52.7\end{array}$ & $\begin{array}{l}1.0 \\
1.0 \\
1.2\end{array}$ & $\begin{array}{l}0.17 \\
0.17 \\
0.21\end{array}$ & $\begin{array}{l}\text { Moderate edems } \\
\text { Edems slightly decreasing } \\
\text { Edems slightly decreasing }\end{array}$ \\
\hline 9 & Perniolous anemis with edems & 60 & M. & W. & $\begin{array}{l}\text { Dec. } 20,1937 \\
\text { Dec. 23, } 1937 \\
\text { Deo. } 30,1937\end{array}$ & $\begin{array}{l}\text { Right pretibial } \\
\text { Right pretibial } \\
\text { Right pretibial }\end{array}$ & $\begin{array}{l}51.5 \\
50.6 \\
51.0\end{array}$ & $\begin{array}{l}52.7 \\
51.7 \\
51.0\end{array}$ & $\begin{array}{l}1.2 \\
1.1 \\
0.0\end{array}$ & $\begin{array}{l}0.21 \\
0.19 \\
0.00\end{array}$ & $\begin{array}{l}\text { Moderate edema } \\
\text { Marked edems } \\
\text { Skin cracking. Bleb forma- }\end{array}$ \\
\hline & & & & & $\begin{array}{l}\text { Feb. 14, } 1938 \\
\text { Mar. 14, } 1938\end{array}$ & $\begin{array}{l}\text { Right pretibial } \\
\text { Right pretiblal }\end{array}$ & $\begin{array}{l}50.5 \\
50.9\end{array}$ & $\begin{array}{l}51.2 \\
52.4\end{array}$ & $\begin{array}{l}0.7 \\
1.5\end{array}$ & $\begin{array}{l}0.12 \\
0.28\end{array}$ & $\begin{array}{l}\text { "Woody" edema } \\
\text { Skin Bofter. Slight edema }\end{array}$ \\
\hline 10 & Neuroblastoma with venous & 6 & F. & C. & Mar. 15, 1938 & Right pretibial & 51.6 & 53.3 & 1.7 & 0.31 & Marked edema \\
\hline $\begin{array}{l}11 \\
12\end{array}$ & $\begin{array}{l}\text { Obstruction } \\
\text { Urticaris } \\
\text { Asoites, cause undetermined }\end{array}$ & $\begin{array}{l}28 \\
57\end{array}$ & $\begin{array}{l}\mathbf{F} \\
\mathbf{M}\end{array}$ & $\begin{array}{l}\text { W. } \\
\text { C. }\end{array}$ & $\begin{array}{l}\text { Feb. 25, } 1938 \\
\text { Feb. 10, } 1938 \\
\text { Feb. 16, 1938 }\end{array}$ & $\begin{array}{l}\text { Dorsum of left hand } \\
\text { Abdomen } \\
\text { Abdomen }\end{array}$ & $\begin{array}{l}50.5 \\
50.8 \\
52.6\end{array}$ & $\begin{array}{l}56.6 \\
52.6 \\
60.5\end{array}$ & $\begin{array}{l}6.1 \\
1.8 \\
7.8\end{array}$ & $\begin{array}{l}1.20 \\
0.31 \\
1.66\end{array}$ & $\begin{array}{l}\text { Wheals disappearing } \\
\text { Marked ascites } \\
\text { After paracentesis }\end{array}$ \\
\hline
\end{tabular}


TABLE II-Continued

\begin{tabular}{|c|c|c|c|c|c|c|c|c|c|c|c|}
\hline$\underset{\text { ber }}{\text { Case }}$ & Diagnosis & Age & Sex & Color & Date & Ares studied & $\begin{array}{l}\text { Dis- } \\
\text { tance } \\
\text { before } \\
\text { otretch- } \\
\text { ing }\end{array}$ & $\begin{array}{l}\text { Dis } \\
\text { tance } \\
\text { after } \\
\text { stretch- } \\
\text { ing }\end{array}$ & $\begin{array}{c}\text { Total } \\
\text { distance } \\
\text { stretched }\end{array}$ & $\begin{array}{l}\text { Dis- } \\
\text { tensi- } \\
\text { bility }\end{array}$ & Remarks \\
\hline 13 & Ascites, cause undetermined & $\begin{array}{c}\text { years } \\
65\end{array}$ & M. & $\mathbf{W}$. & $\begin{array}{l}\text { Feb. 21, } 1938 \\
\text { Feb. 23, } 1938\end{array}$ & $\begin{array}{l}\text { Abdomen } \\
\text { Abdomen }\end{array}$ & $\begin{array}{l}\mathbf{m m} . \\
51.5 \\
51.0\end{array}$ & $\begin{array}{l}m m . \\
53.1 \\
53.2\end{array}$ & $\begin{array}{l}m m . \\
1.6 \\
2.2\end{array}$ & $\mid \begin{array}{c}\text { mw. per } \\
\text { cm. per } \\
100 \text { grams } \\
0.28 \\
0.39\end{array}$ & $\begin{array}{l}\text { Marked ascites } \\
\text { Incomplete paracentesis }\end{array}$ \\
\hline 14 & Ascites, heart failure & 40 & M. & C. & $\begin{array}{l}\text { Feb. 23, } 1938 \\
\text { Feb. 28, } 1938\end{array}$ & $\begin{array}{l}\text { Abdomen } \\
\text { Abdomen }\end{array}$ & $\begin{array}{l}51.3 \\
50.2\end{array}$ & $\begin{array}{l}55.4 \\
58.3\end{array}$ & $\begin{array}{l}4.1 \\
8.1\end{array}$ & $\begin{array}{l}0.77 \\
1.69\end{array}$ & $\begin{array}{l}\text { Moderate ascites } \\
\text { After paracentesis }\end{array}$ \\
\hline 15 & Ascites, carcinomatosis & 47 & F. & C. & $\begin{array}{l}\text { Feb. 28, } 1938 \\
\text { Mar. 2, } 1938\end{array}$ & $\begin{array}{l}\text { Abdomen } \\
\text { Abdomen }\end{array}$ & $\begin{array}{l}50.6 \\
51.7\end{array}$ & $\begin{array}{l}53.2 \\
57.8\end{array}$ & $\begin{array}{l}2.6 \\
6.1\end{array}$ & $\begin{array}{l}0.47 \\
1.22\end{array}$ & $\begin{array}{l}\text { Marked ascites } \\
\text { After paracentesis }\end{array}$ \\
\hline 16 & $\begin{array}{l}\text { Peritonitis (ruptured tubo- } \\
\text { ovarian abscess) }\end{array}$ & 26 & F. & C. & Feb. 21, 1938 & Abdomen & 51.4 & 57.8 & 6.4 & 1.29 & Slight abdominal distension \\
\hline 17 & Peritonitis, tuberculous & 28 & $\mathbf{F}$. & C. & Feb. 21, 1938 & Abdomen & 51.5 & 57.2 & 5.7 & 1.19 & Slight abdominal distension \\
\hline 18 & Senile skin (senile atrophy) & 72 & F. & C. & Feb. 21, 1938 & $\begin{array}{l}\text { Volar surface of left } \\
\text { forearm }\end{array}$ & 50.8 & 55.2 & 4.4 & 0.83 & \\
\hline 19 & Ocoupational atrophy & 31 & $\mathbf{M}$. & W. & Jan. 5,1938 & Dorsum of right hand & 50.4 & 54.4 & 4.0 & 0.75 & \\
\hline 20 & Occupationsl atrophy & 65 & M. & $\mathbf{w}$. & Feb. 21, 1938 & $\begin{array}{l}\text { Volar surface of right } \\
\text { forearm }\end{array}$ & 51.3 & 53.9 & 2.6 & 0.48 & \\
\hline 21 & Occupational atrophy & 64 & $\mathbf{M}$. & W. & Mar. 9, 1938 & Dorsum of right hand & 51.6 & 54.6 & 3.0 & 0.55 & \\
\hline 22 & Allergic eczema & 69 & M. & $\mathbf{W}$. & Feb. 23,1938 & $\begin{array}{l}\text { Volar surface of right } \\
\text { forearm }\end{array}$ & 50.8 & 52.3 & 1.5 & 0.27 & \\
\hline 23 & Scleroderms & 12 & F. & W. & $\begin{array}{l}\text { Nov. 9, } 1937 \\
\text { Nov. 9, } 1937 \\
\text { Mar. 18, } 1938\end{array}$ & $\begin{array}{l}\text { Left pretibial } \\
\text { Right pretibial } \\
\text { Left pretibial }\end{array}$ & $\begin{array}{l}50.0 \\
50.0 \\
50.4\end{array}$ & $\begin{array}{l}50.8 \\
52.5 \\
51.5\end{array}$ & $\begin{array}{l}0.8 \\
2.5 \\
1.1\end{array}$ & $\begin{array}{l}0.13 \\
0.45 \\
0.19\end{array}$ & $\begin{array}{l}\text { Affected side } \\
\text { Unaffected side } \\
\text { Clinically unchanged }\end{array}$ \\
\hline 24 & Soleroderma & 38 & F. & $\mathbf{W}$. & Nov. 11, 1937 & Volar surface of right & 50.0 & 51.3 & 1.3 & 0.22 & Markedly affected \\
\hline & & & & & Nov. 11, 1937 & $\begin{array}{l}\text { Volar surface of left } \\
\text { forearm }\end{array}$ & 52.0 & 54.5 & 2.5 & 0.44 & Moderately affected \\
\hline 25 & Soleroderms & 48 & $\mathbf{M}$. & $\mathbf{W}$. & Nov. 20, 1937 & Dorsum of right hand & 50.6 & 53.3 & 2.7 & 0.48 & \\
\hline 26 & Scleroderms & 42 & F. & $\mathbf{W}$. & $\begin{array}{l}\text { Dec. 18, } 1937 \\
\text { Dec. 18, } 1937\end{array}$ & $\begin{array}{l}\text { Dorsum of left hand } \\
\text { Dorsum of right hand }\end{array}$ & $\begin{array}{l}50.9 \\
50.4\end{array}$ & $\begin{array}{l}53.7 \\
53.4\end{array}$ & $\begin{array}{l}2.6 \\
\mathbf{3 . 0}\end{array}$ & $\begin{array}{l}0.45 \\
0.55\end{array}$ & \\
\hline 27 & Scleroderms & $\mathbf{5 2}$ & M. & W. & $\begin{array}{l}\text { Feb. 16, } 1938 \\
\text { Feb. 16, } 1938\end{array}$ & $\begin{array}{l}\text { Dorsum of right hand } \\
\text { Dorsum of left hand }\end{array}$ & $\begin{array}{l}50.9 \\
50.7\end{array}$ & $\begin{array}{l}54.6 \\
55.3\end{array}$ & $\begin{array}{l}3.7 \\
4.6\end{array}$ & $\begin{array}{l}0.70 \\
0.88\end{array}$ & $\begin{array}{l}\text { Slightly affected } \\
\text { Slightly affected }\end{array}$ \\
\hline
\end{tabular}

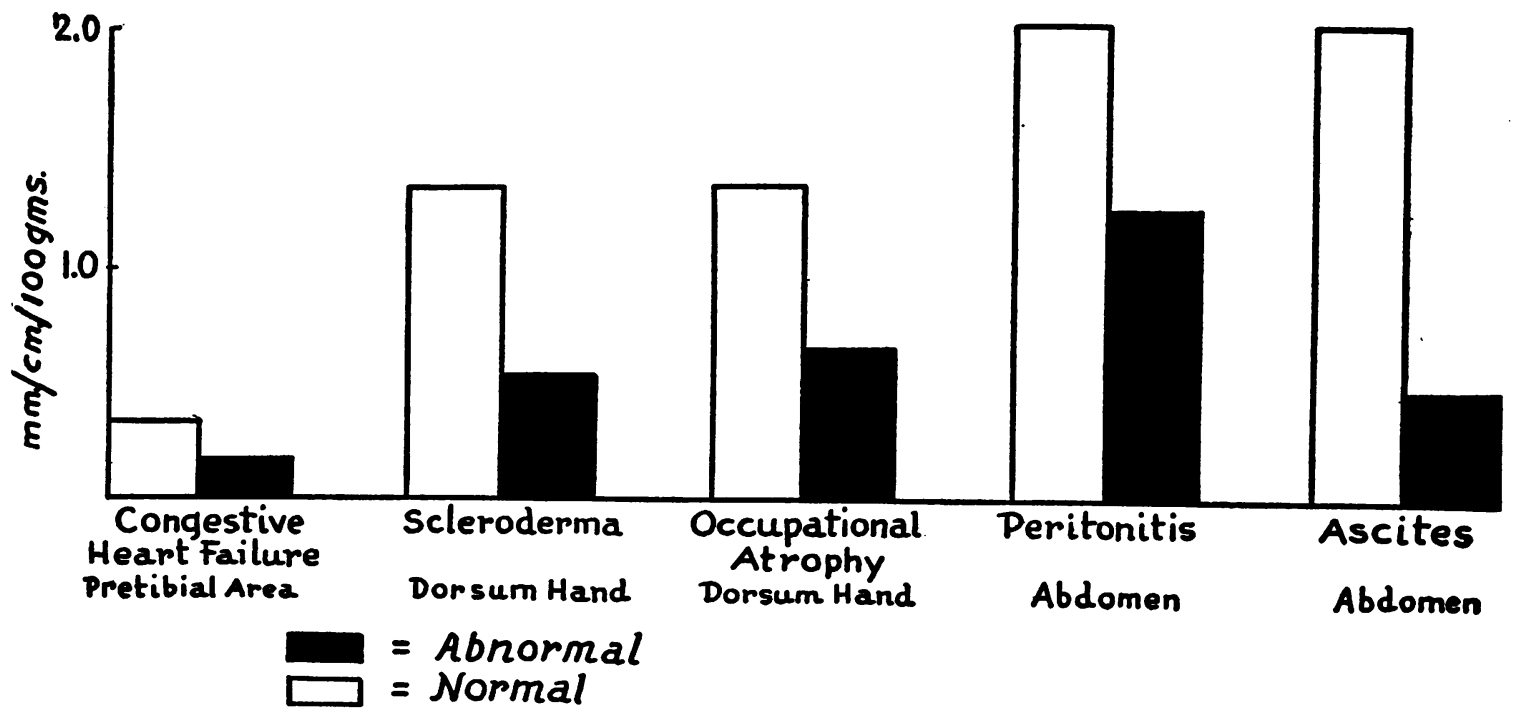

Fig. 5. Comparison of Mean Distenstbility Values in Normal and Abnormal States 
were followed, when possible, through the course of the edema. It was found that as the edema progressed the skin distensibility decreased and with recession of the edema distensibility tended to return to normal range. Essentially the same results were found in the edema of pernicious anemia and that of venous obstruction resulting from neuroblastoma of the adrenal gland. The data for the patient with pernicious anemia and edema, together with simultaneous determinations of tissue pressure, are illustrated in Figure 6.

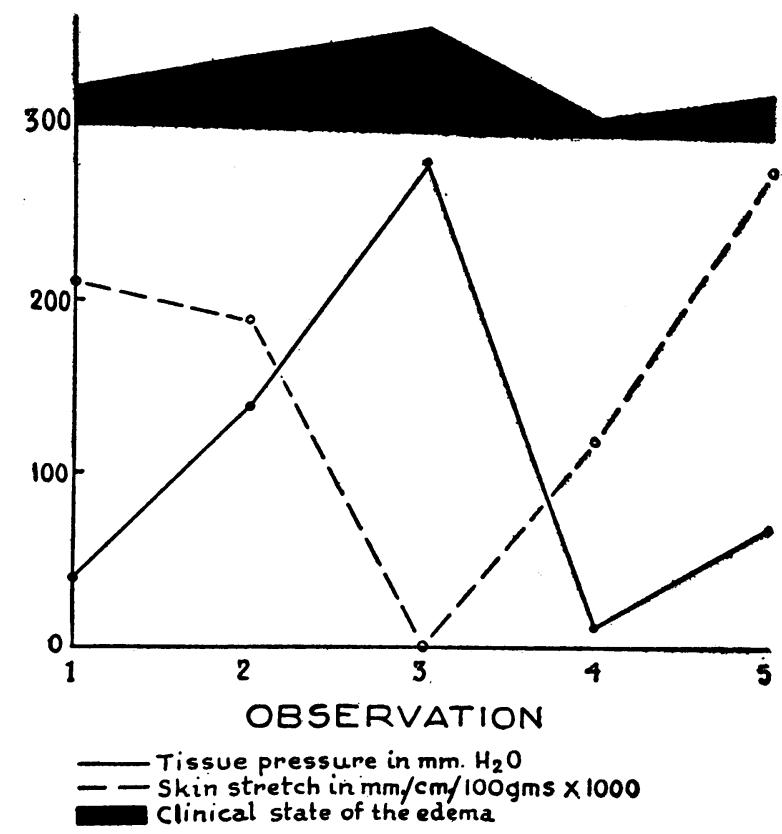

Fig. 6. Illustration of the Course of Tissue Pressure, Skin Distensibility, and Edema in a Patient with Pernicious Anemia

The correlation of these values will be presented under Discussion. Determinations of skin distensibility have been made upon the abdomens of four patients with ascites before and after paracentesis. Marked differences were found as illustrated in Table II. Similar, but less marked changes were found in two patients with peritonitis. In certain dermatologic states (urticaria, senile atrophy, occupational atrophy, allergic eczema, and scleroderma) were observed definite changes in skin distensibility which correlated with the clinical state of the patient. Individual and mean values may be found in Table II and Figure 5.

\section{DISCUSSION}

For a number of years it has been realized (1) that an objective method for measuring skin changes in edematous states would have many important clinical applications. With this is mind, Schade developed his elastometer. His apparatus and the many modifications which have followed it are in reality mechanical palpators, capable of detecting changes too small to be picked up by ordinary clinical methods. The method was also designed to measure skin elasticity, a phase of the apparatus most highly developed in the instrument of Inouye (3). While these methods are valuable in the measurement of certain aspects of tissue turgor, the influence of more deeply underlying structures introduces a variable which precludes their use for the measurement of skin distensibility and elasticity. To obviate the influence of deep structures, as bone and muscles, we undertook to stretch the skin horizontally rather than to depress it. Such a procedure reduces to a minimum the influence of structures below the dermis, and measures as far as possible without removal of the segment of skin the distensibility of the dermis and epidermis. Since the normal skin tension of a given area varies with flexion and extension of adjacent joints and position of a part we found that standard positions were necessary for comparison of results. Again one must be aware, in stretching a segment of the intact skin, that one not only stretches the segment under observation but also puts an oblique stress upon the skin lateral to the segment studied and pushes the skin distal to both ends of the segment. Both of these influences enter into the results of each determination, but are relatively constant from individual to individual and more so in the same individual. As long as the length of skin segment studied is the same, results are comparable from observation to observation and from patient to patient. The only means of eliminating these influences is to remove the skin segment to be studied. Such a procedure offers the disadvantage of necessary surgery, interference with innervation, circulation and the general normal physiology of the part studied, and the inability to do repeated determinations on the same segment during the progress of the disease. 
It should be made clear that our method measures the ability of the skin to stretch-its "stretchability," or distensibility. We cannot measure elasticity in the intact skin in the pure physical sense, nor, indeed, can the methods of others. Stress, or force per unit area, depends upon an exact knowledge of skin thickness, which cannot be satisfactorily measured in the intact skin. Strain is, of course, easily measured. Our method measures the strain produced by a known total force which cannot be converted into force per unit cross-sectional area. This quantitative expression measuring strain per total force rather than strain per unit force lends itself admirably to the objective study of dermatologic changes, particularly in the clinic.

The constancy of our standards in a single site indicates either a constancy of quality and quantity of dermis and epidermis or an inverse relationship between the two, producing a constant relationship in distensibility. Significant variation from the normal would indicate, therefore, that either the quality, the quantity, or both characteristics of the skin have undergone abnormal changes. This is particularly exemplified in scleroderma where our results correlate with well-known pathological changes of dense fibrosis in the dermis.

The normal values for the areas studied have already been given (Table I). It is interesting to note the relatively marked distensibility of the abdominal skin and the relatively non-distensible skin of the lower extremities. Just as quantitative variations in skin thickness are known to occur from person to person in one area, so do quantitative variations occur from area to area in the same individual. The skin thickness is known to vary from approximately $0.37 \mathrm{~mm}$. in the eyelids to $5.0 \mathrm{~mm}$. in the soles and palms. Such variations not only involve the epidermis but the corium as well (11). The observed variations in skin distensibility may be accounted for either by qualitative and quantitative variations or by variations in skin tension in the parts studied. We have previously reported (10) regional variations in tissue pressure which show an inverse relationship to the skin distensibility. This relationship tends to show that the low skin distensibility in the lower extremities is owing, in part at least, to increased skin tension in these parts. This regional variation may be of physiological significance in the prevention of edema of the feet on assuming the erect position.

The great distensibility of the abdominal skin is in accord with the marked physiological variations it must undergo, particularly in pregnancy. We are at present engaged in a study of the changes in skin distensibility of the abdominal skin in and following pregnancy, especially in relationship to striae formation.

Skin distensibility, as we have measured it, may be influenced in abnormal as well as in normal conditions, by at least three factors, (1) variations in skin tension, (2) changes in the quality of the dermal structures, and (3) changes in the quantity of the dermal structures. These factors may variably influence either the epidermis or the corium or both. In our group of patients these variables have come into play, modifying the skin distensibility at times to a marked degree. For example, in ascites caused by portal obstruction or tuberculous peritonitis (see Table II), the change in skin distensibility primarily results from a change in skin tension. Under such conditions, the skin is already stretched by the increased intra-abdominal pressure and the $5 \mathrm{~cm}$. segment of skin measured for study does not represent $5 \mathrm{~cm}$. of undistended skin. The application of the method to the distended skin indicates how much farther this stretched skin can extend with an additional force of 100 grams. Therefore, any changes caused by the disease process would be accurately and quantitatively reflected in the measurements obtained. In the instance of edema, not only does the factor of distension come into play, but there are changes in quality and quantity as well. The distended, shiny skin of edematous parts exemplifies the first factor; changes in elastic fibers, long used as an explanation of pitting edema (12), are indicative of qualitative changes; and actual swelling of the part with separation of dermal structures reduces the unit quantity of such elements. As the disease progresses, all of the factors, interplaying as variables, influence to a changing degree the skin distensibility. The measurements of skin distensibility are quantitative expressions of this composite picture. The physiological sig- 
nificance of these measurements in edema is appreciated when one becomes cognizant of the disturbed equilibrium of filtration and antifiltration. With greater filtration as fluid accumulates, the tissues are stretched and become less distensible. Tissue pressure then rises and tends to equalize the filtration pressure, acting as a limiting factor to the extent of the edema. The loss of skin distensibility, as our results show, is one of the important limiting factors. This effect is illustrated in Figure 6, where it may be seen that, with increasing edema and tissue pressure, there is a concomitant decrease in skin distensibility. It is interesting to note that when the skin distensibility reached its limit for the force applied, the tissue pressure was greatest, the skin was beginning to crack, and bleb formation began. The edema subsided almost completely and tissue pressure returned to normal limits and skin distensibility approached normal. The final observation was taken when the edema increased slightly. At this time the tissue pressure and skin distensibility increased. An explanation for the absence of an inverse relationship between these two determinations at this time can only be conjectured. Physical examination disclosed that skin texture was improving steadily following the period at which its elastic limits were reached. The part was softer and less woody, in spite of the presence of edema. This indicates a qualitative improvement in the skin characteristics. Then, too, the blood hemoglobin was approaching normal, improving the tissue nutrition.

The dermal changes found in scleroderma represent variations in all three factors. Histologically, one can demonstrate qualitative and quantitative changes in the skin elements, particularly in the connective tissue of the corium. The studies of Prinzmetal (13) illustrate definite changes in skin tension. Our studies (14) tend to confirm this observation. These abnormal variations in the physical characteristics of the skin apparently are directly proportional to the severity of the disease. Again, since the distensibility measurements are dependent upon these physical dermal factors, the skin distensibility should vary inversely with the severity of the disease. This was found to be true in the patients studied (Table II). In the parts more severely involved the distensibility values were found to be extremely low, with all values varying with the clinical state of the disease and less than normal for that part. Such findings suggest the tremendous importance of this method of study for quantitatively evaluating the progress of scleroderma. It also lends itself as a simple and rapid method for the early detection of results produced by, and the proper evaluation of, various therapeutic procedures. The method also serves as a tool for the early diagnosis of sclerodermatous changes.

The skin distensibility technic may be applied in the same manner to the study of skin changes in occupational atrophy and other dermatoses affecting the physical properties of the skin.

\section{SUMMARY AND CONCLUSIONS}

A simple and accurate method for the measurement of skin distensibility is described.

The normal mean values for the pretibial area, dorsum of the foot, midline of the abdomen below the umbilicus, volar surface of the forearm and dorsum of the hand were found to be 0.31 , $0.59,2.07,0.93$, and $1.34 \mathrm{~mm}$. per cm. per 100 grams, respectively. The regional variation disclosed less distensible skin in the lower extremities.

Edema, certain vascular diseases, and some dermatoses were found to produce changes in the normal skin distensibility. As edema progressed the skin distensibility decreased and with recession of the edema, distensibility tended to return to normal range. The loss of skin distensibility was found to be an important limiting factor in edema formation. In urticaria, senile atrophy, occupational atrophy, allergic eczema, and scleroderma were observed definite changes in skin distensibility which correlated with the clinical state of the patient. In such diseases the method lends itself as a simple and rapid procedure for the early detection of results produced by and the proper evaluation of various therapeutic procedures.

\section{BIBLIOGRAPHY}

1. Schade, H., Untersuchungen zur Organfunction des Bindegewebes. I. Die Elasticitätsfunction des Bindegewebes und die intravitale Messung ihrer Störungen. Ztschr. f. exper. Path. u. Therap., 1912, 11, 369. 
2. Kunde, M. M., Edema. I. Correlation of elastometer readings, disappearance time for intradermally injected salt solution, urinalysis and nitrogen retention of the blood in edema. Arch. Int. Med., 1926, 38, 57.

3. Inouye, K., Dermoelastometry. I. A new dermoelastometer. Acta scholae med. univ. imp. in Kioto, 1931-32, 14, 229.

4. Inouye, K., Dermoelastometry. II. Clinical investigation into dermoelastometry. Acta scholae med. univ. imp. in Kioto, 1931-32, 14, 232.

5. Inouye, K., Dermoelastometric research: The effect of standing work. Acta scholae med. univ. imp. in Kioto, 1931-32, 14, 276.

6. Trendtel, F., Elastometrische Untersuchungen an Kindern. Ztschr. f. d. ges. exper. Med., 1926, 49, 327.

7. Schwartz, A. B., The clinical study of edema by means of the elastometer. Arch. Int. Med., 1916, 17, 396.
8. Rondelli, U., Sulla misura della "tensione cutanea." Minerva med., 1934, 1, 810.

9. Davis, J. S., Plastic Surgery, Its Principles and Practice. P. Blakiston's Son and Co. Philadelphia, 1919, p. 25.

10. Burch, G. E. and Sodeman, W. A., The estimation of the subcutaneous tissue pressure by a direct method. J. Clin. Invest., 1937, 16, 845.

11. Spalteholz, W., Hand-Atlas of Human Anatomy. J. B. Lippincott. Philadelphia, 1923, 4th English ed.

12. Wiggers, C. J., Physiology in Health and Disease. Lea and Febiger. Philadelphia, 1934, p. 828.

13. Prinzmetal, M., Studies of the mechanism of circulatory insufficiency in Raynaud's disease in association with sclerodactylia. Arch. Int. Med., 1936, 58, 309.

14. Sodeman, W. A. and Burch, G. E., The tissue pressure in subcutaneous edema. Am. J. M. Sc., 1937, 194, 846. 